\title{
Margaret McCartney: The power of patients' stories
}

\author{
Margaret McCartney general practitioner, Glasgow
}

Stories in medicine are often rich in fascination and inspiration. We tell stories to each other all the time: which patients we saw, which ones we visited - and who we have only just realised is related to whom. Stories create sense out of disparate happenings, melding understandings of why things happen and who is affected when they do.

Doctors have always written about how patients made them feel, sometimes in excruciating detail. Stories about patients by healthcare professionals appear in blogs, newspapers, magazines, and books, and they follow a fashionable formula. Patient meets doctor; patient has an unusual symptom or a grim prognosis; doctor faces a dilemma, followed by some combination of self examination, something going wrong, doubt, guilt, and then denouement.

Doctors often write under their own name. Sometimes they admit to changing patients' names. But patients, relatives, and carers may still recognise themselves-or think that they do. What if the story contains new, painful, or worrying information? Such stories could affect the doctor-patient interaction.

And whose stories are these, anyway? Do they belong to patients? Should doctors be telling these tales at all?

As a patient I wouldn't want to feel unable to be completely frank with my doctors, and I would fear publication of my consultations, even if they were anonymised. I assume that many patients want the same. As a doctor I value the privacy of the consulting room and the confidentiality that allows patients to be completely open. Without trust, doctors cannot work.

Here's an admission: in writing my book Living with Dying I wanted to portray how medicine can be used badly at the end of life. I thought that the statistics would make sense only if I could relate them to real life. So I wrote two stories, each a version of the same death. Each was an anecdote, but anecdotes are stories, and stories are powerful illustrations that can make statistics meaningful. I removed all traces of real patients, but I had bought into the common narrative drive.

I was caught in the tension between an absolute need to preserve confidentiality and a wish to explain to a lay audience in human terms some of the muddles we commonly see at the end of life. Was I wrong to include these stories? Doctors have created a marketplace for medical dramatic narrative- but written only in a particular mould.

Medicine, like life, is messy and often uncertain. And much of medicine lacks drama but is still of deep importance. If popular accounts of medicine all rely on the same dramatic arc they may impinge on the patient-doctor relationship, undermining patients' trust that doctors rely on so heavily.

Competing interests: I have read and understood the BMJ policy on declaration of interests and declare the following interests: I'm an NHS GP partner, with income partly dependent on Quality and Outcomes Framework points. I'm a part time undergraduate tutor at the University of Glasgow. I've written two books and earn from broadcast and written freelance journalism. I'm an unpaid patron of Healthwatch. I make a monthly donation to Keep Our NHS Public. I'm a member of Medact. I'm occasionally paid for time, travel, and accommodation to give talks or have locum fees paid to allow me to give talks but never for any drug or public relations company. I was elected to the national council of the Royal College of General Practitioners in 2013 and am chair of its standing group on overdiagnosis. I have invested a small amount of money in a social enterprise, Who Made Your Pants?

Provenance and peer review: Commissioned; not externally peer reviewed.

Follow Margaret on Twitter, @mgtmccartney

Cite this as: BMJ 2015;351:h4259

๑๑ BMJ Publishing Group Ltd 2015 